\title{
Changes of temporospatial orientation in persons with intellectual disabilities who participate in modern dance workshops
}

Authors' Contribution: A Study Design

B Data Collection

C Statistical Analysis

D Data Interpretation

E Manuscript Preparation

F Literature Search

G Funds Collection

\author{
Olga Szymańska ABDEF, Wojciech Wiliński ACDE \\ University School of Physical Education in Wroclaw, Poland
}

abstract

Background:

Material and methods:

The aim of the study was to identify whether participation in a short series of modern dance (hip-hop) workshops could improve the level of temporospatial orientation in persons with moderate intellectual disabilities.

The group consisted of 10 persons aged $14-23(M=19.5, S D=2.87)$. A quasi-experiment was prepared in a one-group plan which consisted of a series of nine modern dance workshops lasting 60 minutes each and held twice a week. The following test layout / testing regime was used: pretest-posttest to check the temporospatial orientation level of dance workshop partic-ipants before and after the workshop. A "ball run" spatial orientation test was used in the study. The test was adapted to the cognitive abilities of the subjects.

Results: Student's t-test for dependent samples showed that the mean level of temporospatial orienta-tion in persons with moderate intellectual disabilities before their participation in nine hip-hop dance workshops $(M=32.32 ; S D=3.98)$ is significantly higher than the mean level of tem-porospatial orientation $(M=29.74 ; S D=5.45)$ after completion of workshops, $t(9)=2.61 ; p<0.05$.

Conclusions: Modern dance (hip-hop) classes improve temporospatial orientation in persons with moderate intellectual disabilities

Key words: temporospatial orientation, intellectual disability, modern dance, hip-hop.

\section{article details}

Article statistics: Word count: 3,178; Tables: 0; Figures: 1; References: 60

Received: June 2020; Accepted: December 2020; Published: December 2020

Full-text PDF:

http://www.balticsportscience.com

Copyright @ Gdansk University of Physical Education and Sport, Poland

Indexation: Celdes, Clarivate Analytics Emerging Sources Citation Index (ESCI), CNKI Scholar (China National Knowledge Infrastructure), CNPIEC, De Gruyter - IBR (International Bibliography of Reviews of Scholarly Literature in the Humanities and Social Sciences), De Gruyter - IBZ (International Bibliography of Periodical Literature in the Humanities and Social Sciences), DOAJ, EBSCO - Central \& Eastern European Academic Source, EBSCO - SPORTDiscus, EBSCO Discovery Service, Google Scholar, Index Copernicus, J-Gate, Naviga (Softweco, Primo Central (ExLibris), ProQuest - Family Health, ProQuest - Health \& Medical Complete, ProQuest - Illustrata: Health Sciences, ProQuest - Nursing \& Allied Health Source, Summon (Serials Solutions/ProQuest, TDOne (TDNet), Ulrich's Periodicals Directory/ulrichsweb, WorldCat (OCLC)

Funding: This research received no specific grant from any funding agency in the public, commercial, or not-for-profit sectors.

Conflict of interests: Corresponding author: Authors have declared that no competing interest exists.

Olga Szymańska, Akademia Wychowania Fizycznego we Wroclawiu - Zakład Metodyki Szkolnej Kultury Fizycznej; ul. Witelona 25 Wroclaw 51-617, Poland; e-mail: olgaszymanska95@gmail.com

Open Access License:

This is an open access article distributed under the terms of the Creative Commons Attribution-Non-Commercial-NoDerivatives 4.0 International (https://creativecommons.org/licenses/by-nc-nd/4.0/), which permits use, distribution and reproduction in any medium, provided the original work is properly cited, the use is non-commercial and is otherwise in compliance with the license. 


\section{INTRODUCTION}

Intellectual disability is a complex condition with diverse clinical presentations determined by different etiological factors. It comprises varied symptoms of development disturbances asso-ciated with genetic disorders, neurodevelopmental disorders, metabolic disorders, neurotoxic infections, but also a result of environmental and cultural factors [1-3]. The DSM-V classifi-cation [4] is based on the fact that intellectual disability is a disorder beginning in the devel-opment period and includes deficits both in terms of intellectual and adaptive performance in areas relating to understanding concepts, social performance and practical fields. Educational possibilities of persons with moderate intellectual disabilities are very limited due to the large abnormalities in mental and physical development. Dysfunctions apply both to motor devel-opment and perception processes. There are also difficulties in moving from a lower level to a higher level of development. These changes are primarily determined by the abnormal perfor-mance shown by the anatomical structures of the brain. ID is classified as neurodevelopmental disorders. The studies carried out so far indicate abnormalities within the structure of the cen-tral nervous system $[5,6]$. Motor coordination is closely linked to the functioning of the central nervous system. It depends on performance of receptors, secretion and transport of hormones by blood and the flow of information through the nervous system. Therefore, thorough coor-dination of movements requires establishment of action programs before the motion com-mences. During the movement, its course is systematically evaluated, and adjustments are made on the basis of the discrepancies between the achieved result and the planned objective of the action [7-16]. Due to the deficits in the correct functioning of the central nervous sys-tem in persons with intellectual disabilities, it can be noted that coordination abilities in this social group are significantly less developed than in an average person with a standard devel-opment status [17]. Taking up physical activities by persons with intellectual disabilities is a very important element in their revalidation/compensation. Therapists or teachers should con-sider what really is important and needed to improve the performance of persons with intellec-tual disabilities when developing programs/curricula for their students. There is no doubt that creation of programs aimed at developing coordination abilities is of utmost importance. Tem-porospatial orientation is determined by the capacity of the central nervous system to func-tion. Efficient CNS enables fast and effective control and adjustment of motion in space [18-27]

Music and dance can provide persons with intellectual disabilities while learning with support and even guidance. Dance lessons are also part of rehabilitation [28] and cognitive, emotional and social therapy [29]. Sooful et al. [30] assume that dance and music encourage personal efforts, enable people to overcome the limitations imposed by their disabilities and help them to achieve a greater sense of accomplishment. A few studies to date showed that motor coor-dination could be shaped through different forms of dance [31-33]. Dance is a form of exer-cise that offers physiological and psychological benefits [34]. In addition, physical training with dancing can improve balance, strength, flexibility and functioning of the cardiovascular system, because it uses interval training but is considered an aerobic form [35]. Haghigh et al. [36] investigated the effect of a combined program (aerobic and rebound therapy) with two different ratios on some physical and motor fitness indices in intellectually disabled girls. The results showed that both exercise programs in experimental groups improved endurance per-formance indices, lower extremities endurance, cardio-respiratory endurance, static and dy-namic balance, agility and coordination in comparison to the control group.

There are many kinds of dance, such as ballroom dance, modern, jazz, ballet and traditional dance. We more often meet with dance in the rehabilitation of people with neurological disor-ders such as Parkinson disease or dementia. In research, we can find the use of such dances as Argentinian tango, Zumba and DMT [37-41]. Modern dance deserves special 
attention, which, thanks to having been popularized by the media, can arouse public interest more easily than other dance variants. Modern dance teaches people to work in space and with space, namely, to move carefully and freely within it [42]. In modern dance you can see the compo-nents of jazz, modern dance, classical dance, stepping, etc. There are many styles of modern dance, e.g. new style, disco dance, dancehall, afro dance, breakdance, street dance, funky. In this collection of many dance techniques, improvised, dynamic and strong movement is what really counts. This area is constantly evolving.

Modern dance, which includes the hip-hop style, originates from the street dance, i.e. dancing in the streets created in 1970s. This dance requires dancers to coordinate their movements very closely. Hip-hop is a dance that is very characteristic, dynamic and lively, because of the uniqueness of many steps and transitions that require bouncing off the ground. The distinctive feature of this dance is a high degree of technical freedom. However, there are rules that any dancer specializing in this style should adhere to. The basis is the so-called "feeling", which means sensing the music, its rhythm, melody, the intensity of the song, which translates into dancers performing the same steps, but music will be interpreted differently. It is all about representation of music through motion as smoothly as possible. The tempo of hip-hop music is in the range of 70 to 130 beats per minute (BPM) [43]. So if we talk about a tempo of music being "at 90 BPM," we mean that there are 90 beats (pulses) every minute. Tempo in hip-hop can be freely selected according to the students' abilities; it is not imposed as in ballroom or folk dances. It is also important to move steadily and isolate the body by moving its individu-al parts precisely. Therefore, training requires learners to work on coordination abilities $[44,45]$. This dance is undoubtedly suitable for persons with intellectual disabilities due to its attractiveness and popularity, which may be an incentive to participate in such a form of phys-ical activity. This activity combines motion, social interaction and play, and in addition, is easy to carry out because it does not require any specialized equipment. In addition, according to the studies by Bonny, Lindberg and Pacampara [46], dance such as hip-hop can contribute to improving cognitive processes and, as we know, it is used to create and modify the knowledge of the environment that shapes our behaviour (to explore the environment), which suggests that this may have a direct effect on temporospatial orientation. It is worth adding that it is difficult to find a similar topic in the literature where authors would undertake to check whether regular hip-hop dance training could improve temporospatial orientation, possi-bly due to the relatively short existence of the dance style.

\section{AIM OF THE STUDY}

The aim of the study was to identify whether participation in a short series of modern dance (hip-hop) workshops could improve the level of temporospatial orientation in persons with moderate intellectual disabilities. Empirical verification of this aim required the following re-search question to be posed:

Does the level of temporospatial orientation in persons with moderate intellectual disabilities change after they have completed nine modern dance (hip-hop) workshops?

\section{MATERIAL AND METHODS}

The criterion for inclusion into the study group was moderate intellectual disability, interest in dance (selection was made by specialists - physical education teachers with professional qual-ifications as teachers of persons with intellectual disabilities) and a written consent from par-ents followed by oral consent from students in order to participate in modern dance work-shops and scientific research conducted on the school premises. 10 out of 14 people were qualified for the research ( 5 men and 5 women) aged 
14-23 $(M=19.5, S D=2.87)$, including a student with severe intellectual disabilities who performed at a similar level as the rest of the group. 4 persons were not qualified due to attendance of less than $50 \%$ at all the activities that took place.

In order to verify the research question raised, a quasi-experiment was prepared in a one-group plan which consisted of a series of nine modern dance workshops (hip-hop) lasting 60 minutes each and held twice a week for persons with moderate intellectual disabilities. The following test layout / testing regime was used: pretest-posttest to check the temporospatial orientation level of dance workshop participants before and after the workshop. The protocol of the dance workshops provided for a warm-up, proper classes (learning choreography based on basic steps of hip-hop such as: "Toy Man"1, "Bart Simpson" 2 or "Bounce" ${ }^{3}$ ) and finally: team-building and stretching physical exercises. Old school steps ${ }^{4}$ were selected because they seem more appropriate for people with intellectual disabilities. The steps above are clearly structured and easy to follow the typical hip-hop pace. The tempo of the music was gradual. It started at 75 BPM and increased go to $95 \mathrm{BPM}$. A video recording was made to document the proce-dures used and to record the hip-hop choreography taught during the study ${ }^{5}$.

The following dependent variables included: the level of temporospatial orientation among the participants of the workshop recorded twice: before and after the modern dance (hiphop) workshop. A "ball run" spatial orientation test [47] was used in the study. The test was adapted to the subjects' cognitive abilities. Instead of digits, students were shown images of popular objects. 5 balls were placed along the circle of $3 \mathrm{~m}$ radius and the sixth ball was placed $1.5 \mathrm{~m}$ outwards - away from the centre of the half-circle. The subject was facing the balls with the heels touching the sixth ball. On the signal, the subject turned around and touched the sixth ball by any hand. At this point, the researcher showed a card in A4 format with a picture of: the heart, the bee, the flower, the sun and the cloud. The subject then ran towards the selected ball showing the same image as was just shown to him/her, approached it and touched it with their hand. Then he or she returned to the ball in the centre. When in con-tact with the ball, the subject was given next information about the direction of the run. In this manner, the subject ran toward all the balls placed along the half-circle, completing the test by touching the central ball. Only a better result out of the two tests was analysed. Since the temporospatial orientation indicator was the duration of the test performed, the lower re-sult values indicate better temporospatial orientation. Measurements were made using an elec-tronic handheld timer (accurate to 0.01 seconds).

\section{RESULTS}

Student's t-test was used for dependent samples. The normality of distribution was confirmed by the Shapiro-Wilk test: $W=0.852 ; p=0.061$. The analysis using student's t-test for depend-ent samples showed that the mean level of temporospatial orientation in persons with moder-ate intellectual disabilities before their participation in nine hiphop dance workshops $(M=32.32 ; S D=3.98)$ is significantly higher than the mean level of temporospatial orientation $(M=29.74 ; S D=5.45)$ after completing the workshops, $t(9)=2.61 ; p<0.05$ (Fig. 1). The value of Cohen's $d=0.57$ indicates an average relationship between the participation in modern dance (hip-hop) workshops and the estimated level of temporospatial orientation.

\footnotetext{
1 "Toy Man" https://www.youtube.com/watch?v=ZyPLvH rre4 [access: 9.05.2020]

2 „Bart Simpson” https://www.youtube.com/watch?v=KX-Nbtnsk1E [access: 9.05.2020]

3 „Bounce” https://www.youtube.com/watch?v=p MY7LlS8c4 [access: 9.05.2020]

${ }^{4}$ Old school steps gave the foundation for hip-hop style; the steps are schematic and have names. Over time, the old school evolved and led to the creation of the new school. As a rule of thumb, it is worth first mastering the old school steps before moving on to the new school.

${ }^{5}$ The author of the study may provide access to the recording. 


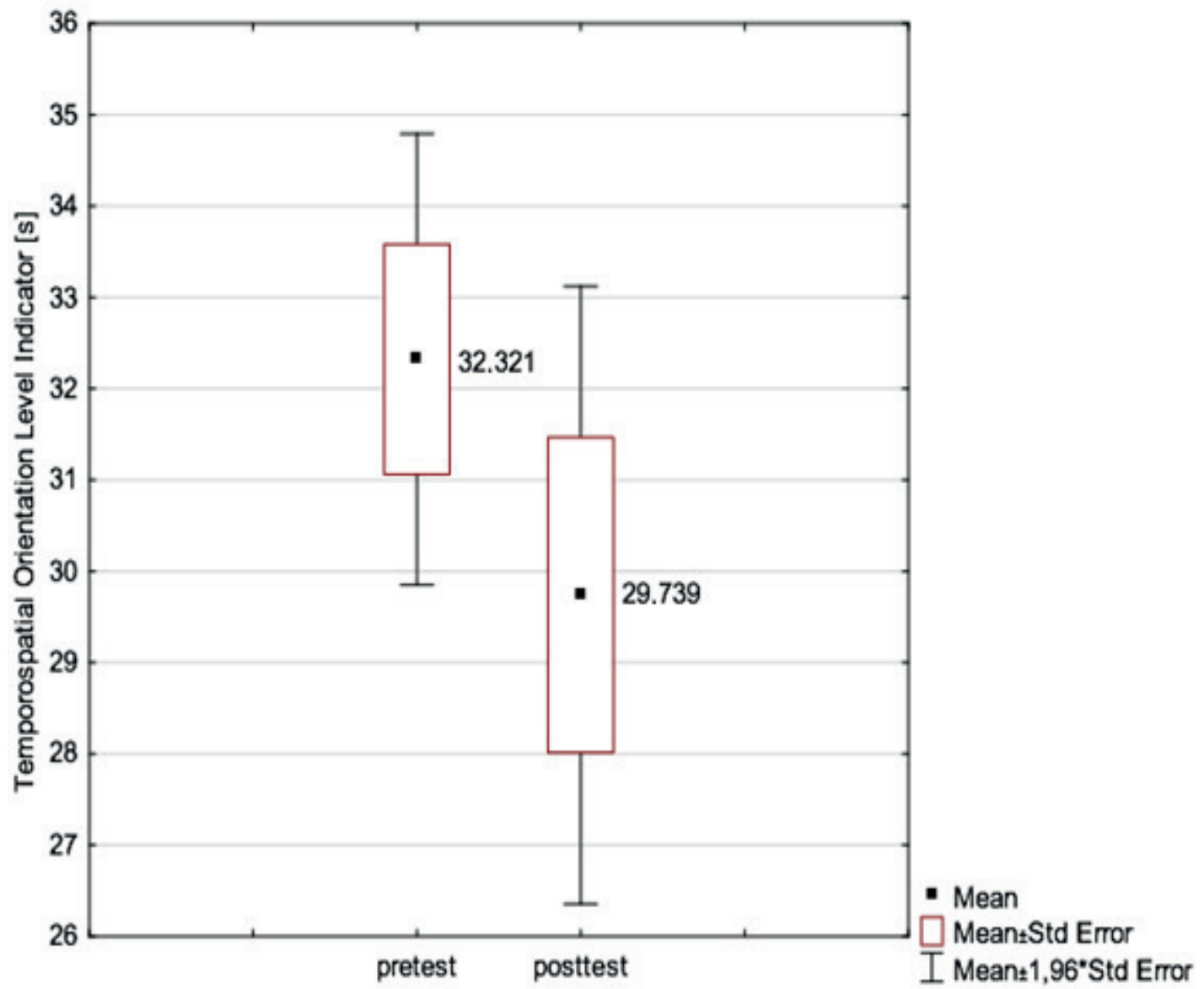

Fig. 1. Average level of temporospatial orientation in persons with moderate intellectual disa-bilities - participants of hip-hop dance workshops before (pre-test) and after (post-test) the workshops. The lower the average, the higher the level of temporospatial orientation

\section{DISCUSSION}

Hip-hop is a dance style that requires a high level of motor coordination. It is based on many complex steps and at the same time gives a dancer a great deal of freedom in interpreting how he or she will perform a given step. Therefore, it is an activity suitable for persons with intel-lectual disabilities. It resembles the process of playing roles in the therapeutic theatre that in-creases the motivation to live. The roles and, in the case of hip-hop, dance forms are proposals that lead to the development of personalities, especially those that are restrained and restricted [48]. In modern dance, and especially in the hip-hop style, the improvisation mentioned above is an important element, for persons with intellectual disabilities can decide how to direct their movement, and instructors can control and dynamise this process, for example by identifying its components. The task of performing dance improvisation consisting of "drawing" circles using different parts of the body is a good example. Participants decide themselves which body parts to use in order to draw circle shapes and at the same time have the frameworks in which they try to perform the task. Such a framework is not based on limitations but on points of reference for the movement performed and on the sense of security.

The results obtained in this study show that following completed hip-hop dance workshops, persons with intellectual disabilities improved their temporospatial orientation. It may suggest the importance of dance in shaping this orientation. Jobling, Virji-Babul and Nichols [49] drew similar conclusions claiming that dance activities could improve the 
sense of rhythm and awareness of the body in persons with Down syndrome. Thus, dance has beneficial effects on the nervous system efficiency and rapid and effective control and regulation of the movement in space [19]. It may be assumed that a high level of body awareness is a factor that deter-mines temporospatial orientation. According to Levy et al. [50], developing awareness of the child's body through organization of impulses and internalization of control is significantly affected by dance. However, before children can cope with external dimensions of the envi-ronment, they must first understand their own body. Using accurate names of body parts and motion directions during dance activities not only expands the development of one's own body awareness, but also that of other people's [51]. For example, Barnet-López et al. [52] carried out studies with adults with intellectual disabilities during which the participants per-formed the human figure drawing test by Koppitz before and after the dance session. The results showed a significant improvement in their body awareness. Therefore, it is an activity suitable for persons with intellectual disabilities. Barnet-Lopez et al. [29] claim that the con-nection between the mind and the body is activated by dance therapy. This is what integrates the emotional, cognitive and physical dimension in a person.

There is no doubt that dance is an activity where coordination abilities play a major role. It appears that physical activity, which focuses on improving motor coordination, can have an impact on cognitive processes [53] responsible for processing information in the nervous sys-tem which ultimately "takes" them back into the environment in the form of reaction - namely behaviours. Kattenstroth et al. [39] think that dancing is increasingly used as an intervention because it combines many diverse features making it a promising neuroplasticity-inducing tool. They performed a broad assessment for people during aging. After 6 months, in the con-trol group no changes or further degradation of performance was found. In the dance group, beneficial effects were found for dance-related parameters such as posture and reaction times, but also for cognitive, tactile, motor performance, and subjective well-being. Scientific re-search confirms that the level of temporospatial orientation can be increased and that it de-pends primarily on the methods used and the selection of motor exercises when creating train-ing programs dedicated to this coordination capacity [54-56]. Gawlik and Zwierzchowska [57] even developed a set of exercises to shape coordination abilities and introduced them in the experimental group of blind persons and partially sighted boys aged 13 to 14 years during all physical education classes. Four dependent variables were controlled: temporospatial orien-tation capacity, dynamic balance ability, rapid simple reaction capability and the ability to move the whole body at high frequencies. The program was implemented over a period of six months and determined a significant improvement of the temporospatial orientation and the rate of response in the study group of subjects with visual impairment. In another study, Jennifer Monique Dabalsa [58] used jazz dance. She created a very diverse group of persons with disabilities. It consisted of 14 students, including persons with Down syndrome, ADHD, MPD and Asperger syndrome with autism spectrum. The classes took place for 12 days and lasted one hour per day during a summer workshop. Spatial orientation is also permanently linked to the perception of temporal parameters of movements and their changes. The level and development depend on the speed of assessment and control of the spatial conditions for the activity, which takes place on the basis of interaction of many analysers, mainly the visual and auditory ones [47]. An example of the fact that dance can shape temporospatial orienta-tion is the study by Jansen [59]. She carried out an experiment involving 65 Bavarian students of the primary school aged 7-9 years. The subjects completed the test which resembled the popular computer-based Tetris logic game and assessed the mental rotation ability. The sub-jects were then divided into two groups. One group went through a five-week creative dance course and the other group attended standard sports classes at school. Interestingly, only chil-dren who learned to dance showed a significant improvement in their mental rotation of fig-ures. The study 
shows that dance improves spatial imagination, which in turn makes it easier to solve all problems in everyday life, e.g. to reach a specific location in a new city. It is worth adding that temporospatial orientation in dance is based, inter alia, on the assessment of the body position during movement, on the ability to use the entire space available to the dancer and to adapt, for example, the length of steps while performing the choreography. During such performance, the group settings are often changed in relation to the frontal wall or in relation to individual participants, which is often beneficial in terms of developing tem-porospatial orientation, limiting the size of the training area and frequent changing of the movement direction [60].

In conclusion, dance offers many advantages in shaping coordination abilities, including tem-porospatial orientation, which "describes" the location of a person or part of his or her body in relation to the reference point and allows him or her to implement the intended movements. This coordination ability is extremely important in daily lives of persons with moderate and severe intellectual disabilities. A high level of temporospatial orientation can provide a basis for increasing autonomy or personal efficacy in persons with intellectual disabilities, which in turn can facilitate their social functioning. Therefore, temporospatial orientation should be included in the revalidation plans for this group of persons and formed during modern dance classes.

\section{CONCLUSIONS}

1. Modern dance (hip-hop) classes improve temporospatial orientation in persons with moderate intellectual disabilities.

2. The results obtained may provide evidence of the positive role played by modern dance in the therapy of nervous system disorders and be another inspiration in the process of developing next choreographies to improve the temporospatial orientation in persons with in-tellectual disabilities.

\section{REFERENCES}

[1] Schroeder S, Gertz G, Velasquez F. Final project report: usage of the term mental retar-dation: language, image and public education. Lawrence: University of Kansas; 2022.

[2] Gottfredson L. Mainstream Science on Intelligence. The Wall Street Journal. 13 December 1994.

[3] Luckasson R, Borthwick S, Buntix WHE. Mental retardation. Definition, classification and system of supports. 10th. Washington: American Association on Mental Retardation; 2002.

[4] American Psychiatric Association. Desk Reference to the Diagnostic Criteria from DSM-5, (2013). (Kryteria diagnostyczne z DSM-5, Polish edition, edited by P. Gałecki, Ł. Święcicki, 2015. Wrocław: Wydawnictwo Edra Urban\&Partner; 2015.

[5] Dierssen M, Ramakers GJA. Dendritic pathology in mental retardation: from molecular genetics to neurobiology. Genes, Brain and Behavior. 2006; 5(Suppl2):48-60. https://doi.org/10.1111/j.1601-183X.2006.00224.x

[6] Lightbody AA, Reiss AL. Gene brain, and behavior relationships in fragile X Syndrome: Evidence from neuroimaging Studies. Dev Disabil Res Rev. 2009;15(4):343-352. https://doi.org/10.1002/ddrr.77

[7] Bernstein NA. Bewegungphysiologie. Sportmedizinische Schriftenreihe, der DHfK. Leipzig. $1975 ; 9$.

[8] Schnabel G. Zur Bewegungskoordination. Wissenschaftliche Zeitschrift der DHfK. Leipzig. $1968 ; 1$.

[9] Schnabel G. Koordinativen Fähigkeiten im Sport - ihre Erfassung und zielgerichtete Aus-bildung. Theor Prax Körperkult. 1974;7:627-632.

[10] Blume DD. Zu einigen wesentlichen theoretischen Grundpozitionen für die Unter-suchung der koordinativen Fähigkeiten. Theor Prax Körperkult. 1978;1:29-36.

[11] Blume DD. Grundsatze und methodische Maßnamen zur Schulung koordinativen Fähigkeiten. Theor Prax Körperkult. 1978;2:3-1

[12] Blume DD. Kennzeichnung koordinativen Fähigkeiten und Möglichkeiten ihrer Herausbildung in Trainingprozess. Wissenschaftliche Zeitschrift der DHfK. Leipzig 1981;22/1:17-41.

[13] Hirtz P. Phänomen koordinativen Fähigkeiten. Theor Prax Körperkult. 1989;Beiheft 2:30-33.

[14] Mattausch WD. Zu einigen Problemen den begrifflichen fizirung den konditionellen und koordinativen Fähigkeiten. Theor Prax Körperkult. 1973;9.

[15] Pöhlmann R, Kirchner G, Wohlgefahrt K. Der Psychomotorische Fähigkeitskomplex seine Kennziechen und seine Vervollkommung. Theor Prax Körperkult. 1979;11:898-907. 
[16] Zimmermann K, Nicklisch R. Die Ausbildung koordinativen Fähigkeiten und ihre Bedeutung für die technische bzw. technisch-taktische Leistungsfähigkeiten der sportler. Theor. Prax. Körperkult. 1981;10.

[17] Smits-Engelsman B, Hill EL. The relationship between motor coordination and intelligence across the IQ range. Pediatrics. October 2012;30(4):e950-e956. https://doi.org/10.1542/peds.2011-3712

[18] Hirtz P, Wellnitz J. Hohes Niveau Koordinativer Fähigkeiten führt zu besseren Ergebnissen im Motorischen Lernen, Theorie und Praxis der Körpererziehung. 1985;4:151-154.

[19] Mynarski W, Raczek J. Zmienność ontogenetyczna wybranych koordynacyjnych zdolności motorycznych u dzieci i młodzieży w wieku 7-18 lat [Ontogenetic variability of selected coordination motor skills in children and adolescents aged 7-18 years]. Antropomotoryka. 1991;6:39-62. Polish.

[20] Šimonek J. Model rozvoja koordinačných schopností v dlhodobej športovej príprave v športových hrách [Model of development of coordination skills in long-term sports training in sports games]. Bratislava: Garmond; 2002, 124137. Slovak.

[21] Waśkiewicz Z. Wpływ wysiłków anaerobowych na wybrane aspekty koordynacji motorycznej [The effect of anaerobic efforts on selected aspects of motor coordination]. Katowice: AWF; 2002. Polish.

[22] Ljach W. Kształtowanie zdolności motorycznych dzieci i młodzieży [Development of motor abilities in children and adolescents] Warszawa: COS; 2003.

[23] Starosta W. Motoryczne zdolności koordynacyjne: znaczenie, struktura, uwarunkowania, kształtowanie [Motor coordination abilities: importance, structure, determinants, development] Wyd. 2. Warszawa: IS; 2003. Polish.

[24] Drid P, Bala G, Obadov S. The differences in motor and cognitive abilities between the more and less successful 12 14 years old judokas. Arch Budo. 2010;6(2):95-100.

[25] Malacko J, Stanković V. Canonical relations between variables of coordination abilities, variables of morphological characteristics and motor abilities of boys aged 11-12. Sport Sci. 2011;1(4):73-77.

[26] Spasovska K. The connection of motorist abilities for assessment the coordination and explosive power with successful perform to gymnastic element, motor in front loom on parallel bars, Activ Phys Educ Sport. 2011;1 (2):129-134.

[27] Yosmaoglu H, Baltaci G, Kaya D, Ozer H. Tracking ability, motor coordination, and functional determinants after anterior cruciate ligament reconstruction. Hum Kinet J Sport Rehabil. 2011;20:207-218. https://doi.org/10.1123/ jsr.20.2.207

[28] Farias LHS, Teixeira-Machado L. Behind the dance: educational, emotional and social contexts in Down syndrome. Int J Humanit Soc Sci Educ. 2016;3(1):20-23. https://doi.org/10.20431/2349-0381.0301005

[29] Barent-Lopez S, Perez-Testor S, Cabedo-Sanroma J, Oviedo GR, Guerra-Balic M. Dance/movement therapy and emotional well-being for adults with intellectual disabilities. Arts Psychother. 2016;51:10-16, 2016. https://doi. org/10.1016/j.aip.2016.08.002

[30] Sooful A, Surujlal J, Dhurup M. Dance and music as mediums for the social integration of children with intellectual disabilities into mainstream society. Afr J Phys Health Educ Recr Dance (AJPHERD). 2010 Dec;16(4):681-697.

[31] Fostiak D. Koordynacja ruchowa u zawodników gimnastyki artystycznej, łyżwiarstwa figurowego i sportowego tańca towarzyskiego [Motor coordination in rhythmic gymnastics, figure skating and dancesport competitors]. Gdańsk: AWF; 1996.

[32] Bednarzowa B, Młodzikowska M. Tańce [Dances]. Gdańsk: WSWF; 1978.

[33] Miura A, Fujii S, Okano M, Kudo K, Nakazawa K. Finger-to-beat coordination skill of non-dancers, street dancers, and the world champion of a street-dance competition. Front Psychol. 201620 April. https://doi.org/10.3389/ fpsyg.2016.00542

[34] Judge JO. Balance training to maintain mobility and prevent disability. Am J Prev Med. 2003;25(3):150-156. https:// doi.org/10.1016/S0749-3797(03)00178-8

[35] Belardinelli R, Lacalaprice F, Ventrella C, Volpe L, Faccenda E. Waltz dancing in patients chronic heart failure. New form of exercise training. Circ Heart Fail. 2008;1:107-114. https://doi.org/10.1161/CIRCHEARTFAILURE.108.765727

[36] Haghigh AH, Mohammadtaghipoor F, Hamedinia M, Harati J. Effect of a combined ex-ercise program (aerobic and rebound therapy) with two different ratios on some physical and motor fitness indices in intellectually disabled girl. Balt J Health Phys Act. 2019;11(1):24-33. https://doi.org/10.29359/BJHPA.11.1.03

[37] Romenets SR, Anang J, Fereshtehnejad SM, et al. Tango for treatment of motor and non-motor manifestations in Parkinson's Disease: a randomized control study. Complement Ther Med. 2015;23:175-184. https://doi.org/10.1016/j. ctim.2015.01.015 doi:10.1016/j.ctim.2015.01.015

[38] Koch SC, Riege RFF, Tisborn K, Biondo J, Martin L, Beelmann A. Effects of dance movement therapy and dance on health-related psychological outcomes. A meta-analysis update. Front Psychol. 2019;10:1806, https://doi.org/10.3389/ fpsyg.2019.01806

[39] Kattenstroth JC, Kalisch T, Holt S, Tegenthoff M, Dinse HR. Six months of dance intervention enhances postural, sensorimotor, and cognitive performance in elderly without affecting cardio-respiratory functions. Front Aging Neurosci. 2013;5:5, https://doi.org/10.3389/fnagi.2013.00005

[40] Kim SH, Kim M, Ahn YB, et al. Effect of dance exercise on cognitive function in elderly patients with metabolic syndrome: A pilot study. J Sports Sci Med. 2011;10(4):671-8.

[41] Rossmeissl A, Lenk S, Hanssen H, Donath L, Schmidt-Trucksäss A, Schäfer J. ZumBeat: Evaluation of a zumba dance intervention in postmenopausal overweight women. Sports (Basel). 2016;4(1):5. https://doi.org/10.3390/ sports 4010005

[42] Siedlecka B, Biliński W. Taniec w edukacji dzieci i młodzieży [Dance in education of children and adolescents]. Wrocław: AWF; 2003, 121.

[43] Moelants D. Dance music, movement and tempo preferences. In: 5th Triennial ESCOM Conference; 2003, 649-652.

[44] Bąk J. Taniec nowoczesny [Modern dance]. Wydawnictwo Dragon; 2016.

[45] Gogerly L. Street dancing (On the radar: Dance). Library Binding; 2011. 
[46] Bonny JW, Lindberg JC, Pacampara MC. Hip hop dance experience linked to socio-cognitive ability. PLoS One. 2017;12(2):e0169947. https://doi.org/10.1371/journal.pone.0169947

[47] Raczek J, Mynarski W, Ljach W. Kształtowanie i diagnozowanie koordynacyjnych zdolności motorycznych. Podręcznik dla nauczycieli, trenerów i studentów [Shaping and diagnosis of coordination motor abilities. Handbook for teachers, trainers and students]. Katowice: AWF; 2003.

[48] Bielańska A. Teatr, który leczy [The theatre that cures]. Kraków: Wydawnictwo Uniwersytetu Jagiellońskiego; 2002. Polish.

[49] Jobling A, Virji- Babul N, Nichols. Children with Down Syndrome: Discovering the joy of movement. J Phys Edu Recr Dance. 2006;77(6):34-38. https://doi.org/10.1080/07303084.2006.10597892

[50] Levy FJ, Fried JP, Leventbal F. Dance and other expressive art therapies- when words are not enough. London and New York: Routledge Taylor\&Francis Group; 2013. https://doi.org/10.4324/9781315811550

[51] Gallo-Lopez L, Rubin LC. Play-based interventions for children and adolescents with autism spectrum disorders. New York, London: Routledge Taylor \& Francis Group; 2012, 333. https://doi.org/10.4324/9780203829134

[52] Barnet-López S, Pérez-Testor S, Cabedo-Sanromà J, Gozzoli C, Oviedo GR, Guerra-Balic M. Developmental items of human figure drawing: dance/movement therapy for adults with intellectual disabilities. Am J Dance Ther. 2015;37(2): 1-15. https://doi.org/10.1007/s10465-015-9201-1

[53] Budde H, Voelcker-Rehage C, Pietrassyk-Kendziorra S, Ribeiro P, Tidow G. Acute co-ordinative exercise improves attentional performance in adolescents. Neurosci Lett. 2008;441(2):219-223. https://doi.org/10.1016/j. neulet.2008.06.024

[54] Ściślak M, Rokita A, Popowczak M. Secondary school students' interest in various forms of physical activity. Hum Mov. 2013;14(1):11-19. https://doi.org/10.2478/v10038-012-0049-7

[55] Koszczyc T. Piłki edukacyjne „Edubal” w kształceniu zintegrowanym. Raport z badań [Educational balls “Edubal” in integrated education. Research Report]. Studia i Monografie 88. Wroclaw: AWF; 2007. Polish.

[56] Rokita A, Rzepa T. While playing - I learn. The educational balls "Eduball" in integrated education. Wroclaw: AWF; 2002.

[57] Gawlik K, Zwierzchowska A. For motion of motor coordination abilities in boys with visual impairment- pedagogical experiment. Fizjoterapia. 2011;19(2):21-27. https://doi.org/10.2478/v10109-011-0015-5

[58] Dabalsa JM. Dance for special needs students: Building Condence and Motor Skills. Student Theses no. 56. University of Northern Colorado; 2017. https://digscholarship.unco.edu/cgi/viewcontent.cgi?article=1113\&context=theses

[59] Jansen P, Kellner J, Rieder C. The improvement of mental rotation performance in second graders after creative dance training. Creative Educ. 2013;4(6):418-422. https://doi.org/10.4236/ce.2013.46060

[60] Karpińska A. Possibilities of shaping motor skills through the contemporary dance. Borgis - Nowa Medycyna. $2000 ; 12$. 